\title{
ENHANCING CORPORATE DEMOCRACY BY THE USE OF SHAREHOLDER PROXIES
}

\author{
Maleka Femida Cassim* \\ MBBCh (cum laude) LLB (cum laude) LLM (cum \\ laude) $P h D$ \\ Professor, Department of Mercantile \\ Law, University of Pretoria \\ Attorney and Notary Public of the High Court of \\ South Africa
}

\section{SUMMARY}

Effective shareholder control over the board of directors is patently in the interests of good corporate governance, accountability and transparency. In recognition of this modern reality, the policy focus in company law has shifted to encouraging shareholder participation and shareholder engagement in corporate affairs. Bearing in mind that very few shareholders of large public companies attend meetings in person, proxy voting is of vital importance to corporate democracy. This article discusses enhanced rights conferred by the Companies Act 71 of 2008 in relation to shareholder proxies who attend, speak and vote at shareholders' meetings. It also considers the pressing practical question whether companies may impose a cut-off time for the lodgement of shareholder proxies.

\section{INTRODUCTION}

The lifeblood of a company is its shareholders. The traditional forum for the exercise of the powers of shareholders is the company's general meeting, at which shareholders make collective decisions by passing ordinary and special resolutions. The original rationale for the legal requirement that companies hold shareholders' meetings attended in person by shareholders was that personal attendance was instrumental in promoting shareholder debate on corporate matters and shareholder voting. ${ }^{1}$ Modern developments have resulted in the loss of significance of the formal general meeting as a forum for decision making by shareholders of small private companies; the contemporary trend for shareholders in small private companies is now to rely more on written resolutions ${ }^{2}$ or even on unanimous assent. In large public companies with widely dispersed shareholders, the machinery of

\footnotetext{
The author is grateful to the National Research Foundation (NRF) for funding this research. Byng v London Life Association Ltd [1990] Ch 170.

See $s 60$ of the Companies Act 71 of 2008 (the Act).
} 
corporate democracy (the law of shareholder meetings, including quorums, voting and proxies) operates in a different context to that in small private companies. It is rarely practical in large companies, with hundreds or even thousands of shareholders, for the majority of the shareholders to be physically present at shareholders' meetings; and such meetings are generally known to be poorly attended. The time, trouble and expense involved in attending shareholders' meetings are strong deterrents, especially for small individual investors who have not only little influence but also a minimal interest at stake.

For shareholders to have a viable means of engaging in the governance of companies, it is essential for company law to provide alternatives to personal attendance at shareholders' meetings. Effective shareholder control over the board of directors, through shareholders' meetings, is patently in the interests of good corporate governance, accountability and transparency. In recognition of these practical realities, the modern policy focus in company law has shifted to encouraging shareholder participation and shareholder engagement in the affairs of the company. This is implicit in the purposes of section 7(b)(iii), ( ) and (I) of the Companies Act 71 of 2008 (the Act), which is aimed at encouraging transparency and high standards of corporate governance, promoting the efficient and responsible management of companies, and balancing the rights and obligations of shareholders and directors within companies.

To advance shareholder participation and shareholder democracy, the Act pioneers innovative provisions to promote the use of information technology and electronic communication in the conduct of shareholders' meetings, and to improve the rights of shareholder proxies to attend, speak and vote at shareholders' meetings. ${ }^{3}$ Both hybrid shareholder meetings and virtual-only meetings are now permissible. Companies may now provide for shareholders' meetings to be conducted entirely by electronic communication (virtual-only meetings) as long as all shareholders ${ }^{4}$ are able to participate effectively and to communicate concurrently with each other without the need for an intermediary. Companies may also usefully make provision, in a shareholders' meeting that is being held in person, for shareholders or shareholder proxies to participate in the meeting by means of electronic communication (hybrid shareholder meetings). ${ }^{5}$ Since very few shareholders of public companies attend meetings in person, proxy voting is of vital importance to corporate democracy.

\section{THE ENHANCED RIGHTS OF SHAREHOLDER PROXIES}

The term "proxy" refers both to the person appointed to represent a shareholder at a meeting as well as the instrument by which such a person is appointed and authorised to exercise voting rights. ${ }^{6}$ At common law,

See $s 58$ of the Act.

Or persons participating in the meeting.

S 63(2) (a) and (b) of the Act.

$6 \quad$ Nuwe Suid-Afrikaanse Prinsipale Beleggings (Edms) Bpk v Saambou Holdings Ltd 1992 (4) SA 387 (W) 390. 
shareholders were required to attend meetings and vote in person. A shareholder who was unable to attend in person did not have an absolute right to appoint a proxy to attend and vote at the meeting on his or her behalf unless the company's constitution provided for this.

The right of shareholders to attend a meeting of the company by proxy is a right conferred by statute. The Act enhances and improves the rights of shareholder proxies to attend, speak and vote at shareholders' meetings. The new provisions on proxies are plainly designed to promote shareholder participation in company affairs. In considering the provisions on shareholder proxies, it must be borne in mind that the effectiveness of proxies as a corporate governance device is open to dispute, as proxies may in practice be used to secure a dictatorship of the board rather than for their proper purpose of furthering shareholder democracy and shareholder control. The provisions of the Act on shareholder proxies do, however, contain some protective measures to counter the misuse of proxies by the board.

The Act, in section 58(1)(a), provides that any shareholder of a company has the right to appoint another person as his or her (or its) proxy to attend and to speak and vote at a shareholders' meeting of the company. Despite the use of the words "may appoint" (emphasis added), this provision is a mandatory requirement that no company may alter or negate in its Memorandum of Incorporation (MOI). ${ }^{8}$ The word "may" is used in section $58(1)(a)$ because the right of a shareholder to appoint a proxy is an entitlement but not an obligation. The provisions on shareholder proxies apply to all companies, and apply equally to non-profit companies with voting members despite their lack of share capital. ${ }^{9}$ In order to promote awareness of shareholders' rights, the Act requires a company to inform shareholders of their statutory rights to be represented by proxy at a shareholders' meeting. In this regard, a notice that convenes a shareholders' meeting of the company must state, with reasonable prominence, the statutory rights of shareholders to appoint a proxy. ${ }^{10} \mathrm{~A}$ proxy need not be a shareholder of the company. ${ }^{11}$ This makes it far easier for a shareholder to find a suitable proxy, as he or she is not limited to fellow shareholders, particularly in cases where he or she wishes to vote against a proposal of the board of directors.

A proxy appointment need not instruct the proxy on which way to vote on a particular resolution. Unless a shareholder has indicated on the relevant proxy form the manner in which the proxy should vote, the proxy may vote or abstain from voting as he or she thinks fit. ${ }^{12}$ A "two-way" proxy form enables shareholders to direct their proxies whether to vote for or against a particular resolution, while a "three-way" proxy form provides also for an option to instruct the proxy to abstain from voting. If the company supplies a form of instrument for appointing a proxy, or issues an invitation to shareholders to appoint a specific person named by the company as a proxy, the invitation or proxy form must provide adequate space for the shareholder to indicate

\footnotetext{
Harben v Phillips (1883) 23 ChD 14 (CA).

See further heading 43 below.

See further heading 42 below.

$\mathrm{S} 62(3)(e)$ of the Act.

$S 58(1)$ of the Act.

S 58(7) of the Act.
} 
whether the proxy is to vote in favour of or against any resolution or is to abstain from voting. This requirement does not apply, however, where the company merely supplies a generally available standard form of proxy appointment on request by a shareholder. ${ }^{13}$

The statutory provisions on company-sponsored invitations to appoint a proxy are designed to prevent the board of directors from using shareholders' proxies in their own favour as a means of securing board control, rather than using them for their intended purpose of enhancing shareholder participation in company affairs. In this regard, if a company issues an invitation to shareholders to appoint as proxy a particular person or persons named in the invitation, such as the chairman of the meeting, the invitations must be sent to all shareholders entitled to notice of the shareholders' meeting and not selectively to just some of the shareholders. ${ }^{14}$ This requirement forestalls the board of directors from soliciting the proxies of only those shareholders whom they expect to vote in favour of their proposals. ${ }^{15} \mathrm{~A}$ company-sponsored invitation, moreover, must contain adequate blank space for a shareholder to indicate an alternative name of another proxy of his or her own choice. It must also provide adequate space for the shareholder to direct the proxy on which way to vote (that is, in favour, against, or abstain). ${ }^{16}$

A shareholder is entitled, unless the MOI provides otherwise, to appoint two or more persons concurrently as proxies, and may appoint more than one proxy to exercise voting rights attached to different securities held by the shareholder. ${ }^{17}$ This provision enables a shareholder to appoint more than one proxy in relation to a particular meeting to exercise the rights related to different shares, and to instruct those proxies to vote differently on particular resolutions. Such flexibility is useful for fund managers or for nominee shareholders who hold shares for a number of different beneficial owners the differing views of the beneficial shareholders may be represented at the meeting through the appointment of multiple proxies. The previous Companies Act 61 of 1973 (the 1973 Act), in contrast, prevented the shareholders of a private company from appointing more than one proxy unless this was provided for in the company's articles of association. ${ }^{18}$

Insofar as methods of voting are concerned, the Act improves the voting rights of shareholder proxies. A proxy may vote on a poll (as was the case under the 1973 Act), ${ }^{19}$ and may even demand or join in a demand for a poll. ${ }^{20}$ A proxy may now also be appointed by a shareholder to give or withhold consent on his behalf to a written resolution passed in terms of section $60 .{ }^{21}$ Furthermore proxies may participate in shareholders' meetings

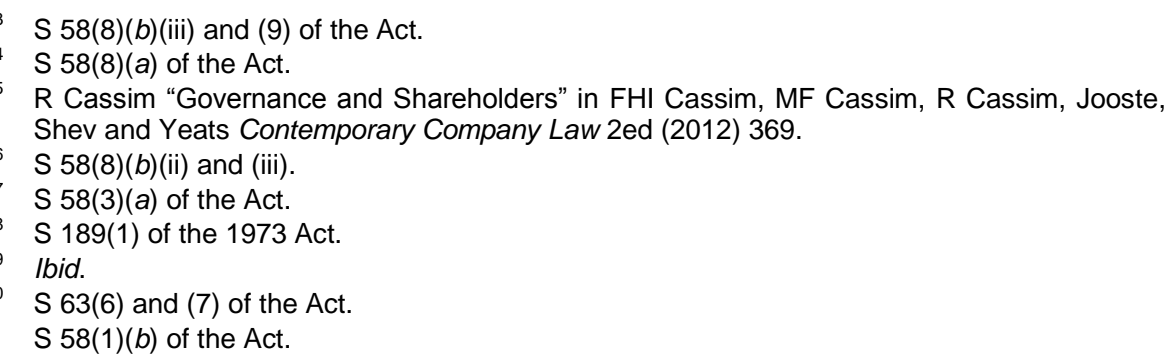


by electronic communication. ${ }^{22}$ While under the repealed 1973 Act a proxy was not automatically permitted to vote on a show of hands unless provided for by the company's articles of association, the Act now explicitly permits proxies to vote on a show of hands. ${ }^{23}$ Where voting is by a show of hands, each person who is present at the meeting, whether as a shareholder or as a proxy, has only one vote. It is a head count. This means that even if a proxy represents several shareholders at the meeting, and even if the proxy has been instructed by some of those shareholders to vote in favour of the resolution and by others to vote against it, the proxy nonetheless has only one vote on a show of hands. This could result in a dilemma for the proxy, or even allow the proxy to "cherry-pick" during voting. It is submitted that the proper avenue for a proxy who has such conflicting instructions would be to abstain completely from voting on a show of hands.

The Act also strengthens the rights of shareholders to appoint and terminate proxies. These issues are discussed separately under heading 3 immediately below.

\section{THE APPOINTMENT AND TERMINATION OF PROXIES}

With regard to the appointment of proxies, the instrument appointing a proxy must be in writing and be signed and dated, ${ }^{24}$ and a copy of the proxy instrument must be delivered to the company or a designated person before the proxy exercises any rights of the shareholder at the relevant shareholders' meeting. ${ }^{25}$ Notably, section $58(3)(c)$ of the Act only requires delivery of a copy of the proxy instrument, and not the original proxy instrument itself. A copy of the proxy instrument may be delivered to the company by various methods, including fax or e-mail. In this regard, the Companies Regulations permit delivery of a document in any manner set out in Table CR $3,{ }^{26}$ which includes delivery by fax, e-mail or registered post. It moreover suffices to deliver a document in terms of the Act by electronic communication of an electronic original or reproduction. ${ }^{27}$ If a proxy form is sent by electronic mail to the company, it is deemed to have been delivered to the company on the date and at the time recorded by the computer used by the sender unless there is conclusive evidence to the contrary. In contrast, when a proxy form is faxed to the company, unless there is conclusive evidence to the contrary, it is deemed to have been delivered to the company on the date and at the time recorded by the fax receiver. ${ }^{28}$

The right to appoint a proxy would be futile if proxy appointments had to be made many days or weeks in advance of the relevant shareholders' meeting. An unreasonably short time period for the lodgement of proxies could also be used unfairly to favour the board. The Act, consequently,

Unless prohibited by the company's MOI; see s 63(2) of the Act.

S 189(1) of the 1973 Act and s 63(5) of the Act.

$\mathrm{S} 58(2)(a)$ of the Act.

Except to the extent that the $\mathrm{MOI}$ provides otherwise; see s 58(3)(c) of the Act.

Regulation 7(1)(b) of the Companies Regulations GNR 351 GG 34239 of 26 April 2011.

$S 6(11)(b)$ of the Act.

See Table CR 3 of the Companies Regulations. 
allows for the appointment of a proxy "at any time", ${ }^{29}$ and for the delivery to the company of (a copy of) the proxy form at any time before the proxy exercises the shareholder's rights at a shareholders' meeting unless provided otherwise in the company's MOI. ${ }^{30}$ Strikingly, the new Act removes the time restriction for the appointment of proxies that applied under the previous company law regime. In this regard, the 1973 Act had permitted the articles of a company to impose a cut-off point by which time the proxy appointment had to be delivered to the company in order for the appointment to be effective at the meeting, although the cut-off point could not be earlier than 48 hours before the relevant shareholders' meeting. Section 189(3)(a) of the 1973 Act provided that:

"Any provision contained in a company's articles shall be void insofar as it would have the effect of requiring the instrument appointing a proxy ... to be received by the company at its registered office or by any other person more than forty-eight hours before a meeting in order that the appointment may be effective thereat".

Pursuant to this provision in the 1973 Act, the articles of association of most companies invariably required the instrument appointing a proxy to be deposited at least 48 hours before the appointed time for holding the meeting, failing which the proxy instrument would be treated as invalid. While the articles could provide for a period shorter than 48 hours, they could not provide for a period longer than 48 hours. If the articles were silent on the matter, proxies could even be lodged at the shareholders' meeting itself. $^{31}$

The purpose of imposing a cut-off time for the submission of proxies under the previous company law regime was to give the company the time and opportunity to process the proxy forms and to scrutinise their validity before the proxies attended and voted at the meeting. ${ }^{32}$ The processing of proxy appointments and terminations, particularly in large public companies with thousands of shareholders, is in practice a laborious and timeconsuming task. Before a proxy may attend a meeting, he or she must present reasonably satisfactory identification, and the person presiding at the shareholders' meeting must be reasonably satisfied that the right of the proxy to participate in and to vote at the meeting has been reasonably verified. It may also be necessary to verify that the shareholder by whom the proxy was appointed was a registered shareholder with voting rights as at the record date for the meeting.

In sharp contrast with the 1973 Act, the current Act contains no cut-off time for the lodgement of proxies, but permits proxy instruments to be lodged at any time before the meeting and presumably even at the meeting itself. This flexibility gives shareholders greater leeway to decide whether to attend the meeting personally or whether to appoint a proxy. It no longer forces them to take a decision two days before the meeting. It also enables

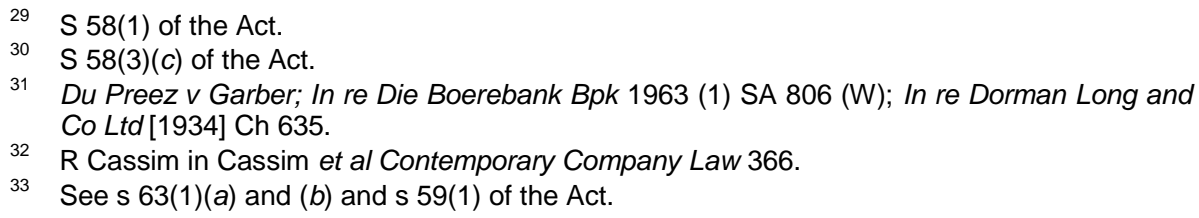


shareholders to appoint a proxy at the eleventh hour if they are unexpectedly prevented from attending a shareholders' meeting. The disadvantage from the company's perspective, though, is that the company no longer has the 48-hour window period to establish which proxies will be attending the meeting. The burning practical question thus arises whether under the new company law regime a company may validly insert in its $\mathrm{MOI}$ a time limit or cut-off time by which shareholders must lodge their proxy instruments with the company. A ruling on this fundamentally important matter was recently made by the Supreme Court of Appeal in Barry v Clearwater Estates NPC (the Clearwater case). ${ }^{34}$

Before turning to the Clearwater case, it may be useful to discuss briefly the termination of a proxy appointment. A shareholder may revoke a proxy appointment by cancelling it in writing or by making a later inconsistent appointment of a proxy - that is, by appointing a different person as proxy and delivering a copy of the revocation instrument both to the proxy and to the company. ${ }^{35}$ This provision protects the company in the event that the company has not been notified of the termination of the proxy's authority before the relevant shareholders' meeting. Thus, where the revocation instrument has not been delivered to the company, the proxy's vote at the meeting would still be valid. The revocation of a proxy instrument is a complete and final cancellation of the proxy's authority as at the later of: the date on which the revocation instrument was delivered to the company and the proxy; or the date stated in the revocation instrument. ${ }^{36}$

It is submitted that on a literal reading of section $58(4)(c)$ of the Act read with section 58(5), a company is not permitted to specify in its $\mathrm{MOI}$ a cut-off time for shareholders to deliver to the company notice of revocation of a proxy's authority; a proxy appointment may thus be revoked at any time before the meeting and even at the meeting itself. The proscription of any deadline for the termination of a proxy's authority under the Act is in harmony with the proscription of a deadline for the appointment of proxies.

Notably, the Act now captures in statutory form the common-law position, as laid down in Cousins $v$ International Brick Co $\mathrm{Ltd}^{37}$ - namely, that the appointment of a proxy is automatically suspended if the principal (the shareholder) at any time chooses to attend and vote in person at the meeting. ${ }^{38}$ The common-law principle is that the personal attendance of the shareholder at a meeting amounts to an implied revocation of the proxy appointment, on the ground that there is no need for the proxy unless the shareholder is unable to attend the meeting. ${ }^{39}$ A standing proxy (that is, a proxy that is not limited to a particular meeting) will be suspended, but not revoked, when the shareholder attends a specific meeting; the result is that

\footnotetext{
2017 (3) SA 364 (SCA).

$S 58(4)(c)$ (i) and (ii) of the Act.

$S 58(5)$ of the Act. Where a company issues an invitation to shareholders to appoint one or more persons named by the company as a proxy, or supplies a form of instrument for appointing a proxy, the appointment remains valid only until the end of the meeting at which it was intended to be used, subject to s $58(5)$ (s 58(8)(d)).

37 [1931] 2 Ch 90 (CA).

$38 \mathrm{~S} 58(4)(a)$ of the Act.

39 Cousins v International Brick Co Ltd supra.
} 
the standing proxy remains valid at future meetings that are not personally attended by the shareholder. ${ }^{40}$

\section{MAY COMPANIES IMPOSE A CUT-OFF TIME FOR LODGEMENT OF PROXIES?}

\section{The facts of the Clearwater case}

In Barry $v$ Clearwater Estates NPC, ${ }^{41}$ the catalyst that ignited the dispute between a homeowners' association incorporated as a non-profit company and its director was a special resolution that approved an increase in the levies payable by the residents of Clearwater Estates NPC. The increase in the levies was recommended in a report prepared by an investigative team and which had been furnished to the members of Clearwater Estates NPC in advance of the special general meeting at which the resolution had been considered. The appellant, a director of the homeowners' association, sought to defeat the special resolution by challenging the validity of certain shareholder proxies (or to be more accurate, the proxies of the voting members of the non-profit company) that had been submitted on the day of the special general meeting of Clearwater Estates NPC.

To this end, the appellant relied on articles 13.7 .10 and 13.7.11 of the $\mathrm{MOI}$ of Clearwater Estates NPC, which provided that any instrument appointing a proxy should be deposited at a designated place not less than 48 hours before the appointed time of the meeting at which the proxy was to be exercised, failing which the proxy would be treated as invalid. The appellant's contention was that the late proxies (filed on the date of the meeting) were invalid, and that discounting these late proxies, the attendance at the meeting had failed to satisfy the requisite quorum of at least 25 per cent of the voting rights being present at the meeting in order to pass a special resolution. It was consequently contended that in the absence of the requisite quorum, the meeting was not properly constituted and the special resolution was invalid. The appellant further asserted that a resolution passed at the meeting to condone the late filing of proxies was similarly invalid.

\section{The legal issue in the Clearwater case}

To resolve this dispute, the Supreme Court of Appeal had to consider section $58(1)$ (a) of the Act, which states:

"[a]t any time, a shareholder of a company may appoint any individual, including an individual who is not a shareholder of that company, as a proxy to participate in, and speak and vote at, a shareholders meeting on behalf of the shareholder".

At first blush, section 58(1) on its literal wording would appear to apply only to "shareholders" in a profit company or a company with shares, as

40 Ibid.

41 Supra. 
opposed to "members" of a non-profit company such as Clearwater Estates NPC. Section 10(4) of the Act, however, puts it beyond any doubt that a reference in the Act to "a shareholder" is a reference to the voting members of a non-profit company. The statutory provisions on shareholder proxies thus extend to the proxies of voting members of non-profit companies. Similarly, the principles laid down by the Supreme Court of Appeal in the Clearwater case apply equally to shareholder proxies in profit companies.

The main issue before the Supreme Court of Appeal was whether section $58(1)$ of the Act is an "alterable provision" or an "unalterable provision". By way of background, "unalterable provisions" are the mandatory or core requirements with which the $\mathrm{MOI}$ of every company must comply. These core requirements are aimed at protecting the interests of shareholders, creditors and third parties who deal with the company. ${ }^{42} \mathrm{~A}$ "provision of th[e] Act that does not expressly contemplate that its effect on any particular company may be negated, restricted, limited, qualified, extended or otherwise altered in substance or effect by a company's Memorandum of Incorporation" amounts to an "unalterable provision". ${ }^{43}$ "Alterable provisions", in contrast, are default rules that a company may either adopt or alter in its $\mathrm{MOI}$. Most alterable provisions contained in the Act are opt-out provisions rather than opt-in provisions - that is, these statutory provisions apply automatically to a company unless it specifically opts out of such provisions in its $\mathrm{MOI}$. The alterable provisions are aimed at providing the flexibility for companies to mould the contents of their constitutions to suit their particular needs. $^{44}$

The significance of the distinction between "alterable" and "unalterable" provisions is that every company is prohibited, by section $15(2)(d)$ of the Act, from including in its $\mathrm{MOI}$ "any provision that negates, restricts, limits, qualifies, extends or otherwise alters the substance or effect of an unalterable provision of the Act except to the extent contemplated in [section 15(2)](a)(iii)". The prohibition in section 15(2)(d) is reinforced by section 15(1) of the Act, which prevents a company from contracting out of the unalterable provisions of the Act by providing:

"[e]ach provision of a company's Memorandum of Incorporation-

(a) must be consistent with this Act; and

(b) is void to the extent that it contravenes, or is inconsistent with, this Act." [emphasis added]

The prohibition in section 15(2)(d) is, significantly, subject to an important qualification. In this regard, section $15(2)(a)$ (iii) of the Act permits a company's MOI to alter an unalterable provision, but only to the extent that it imposes a more onerous requirement on the company, such as a higher standard, a greater restriction or a longer period of time, than that contained in the relevant unalterable provision of the Act.

42 MF Cassim "Formation of Companies and the Company Constitution" in FHI Cassim, MF Cassim, R Cassim, R Jooste, J Shev and J Yeats Contemporary Company Law 125.

$43 \mathrm{~S} 1$ of the Act.

44 MF Cassim in Cassim et al Contemporary Company Law 126. 


\section{Analysis of the ruling in Clearwater}

The Supreme Court of Appeal found that section 58(1) of the Act, which confers an unqualified right on a shareholder to appoint a proxy "at any time", is not an alterable provision but is an unalterable provision. This was on the ground that the provision does not expressly contemplate its alteration in any way by a company's MOI. ${ }^{45}$ Articles 13.7 .10 and 13.7.11 of the $\mathrm{MOI}$ of Clearwater Estates NPC sought to invalidate the appointment of a proxy ${ }^{46}$ if the instrument appointing the proxy was not deposited within a particular time period of at least 48 hours before the appointed time for the meeting. Since these particular articles sought to alter the effect of section $58(1)$ of the Act by placing a limitation on the ability of a member to appoint a proxy less than 48 hours before a meeting, ${ }^{47}$ articles 13.7 .10 and 13.7.11 were inconsistent with the unalterable provision in section 58(1) of the Act. As such, they were consequently void in terms of section 15(1) of the Act. ${ }^{48}$ The result was that the members of Clearwater Estates NPC had an unrestricted right to appoint a proxy at any time, and that the instrument appointing the proxy could be delivered to the company at any time before the proxy had exercised the rights of the member at the meeting. ${ }^{49}$ The practical outcome of the decision was that the proxies in dispute had been properly considered and taken into account at the special general meeting of Clearwater Estates NPC, and the disputed resolutions were found to have been validly passed.

The Supreme Court of Appeal undoubtedly arrived at the correct decision. While the Supreme Court of Appeal did not consider the qualification contained in section 15(2)(a)(iii) of the Act, the qualification was clearly not applicable in this case. Section 15(2)(a)(iii) (which permits the MOl of a company to alter an unalterable provision insofar as it imposes on the company a longer period of time than would otherwise apply to the company under the unalterable provision) applies only where the lengthier period of time is more onerous, not less onerous, to the company. In the Clearwater case, the imposition by the MOI of a time period of 48 hours for delivery of the proxy instrument was a requirement that was more onerous to the company's members, but less onerous to the company itself. As such, it did not fall within the ambit of the qualification contained in section 15(2)(a)(iii).

In deciding this matter, the Supreme Court of Appeal was also required to consider section 58(3)(c) of the Act, and specifically the wording of this provision read together with section $58(1)(a)$. Section $58(3)(c)$ states:

"[e]xcept to the extent that the Memorandum of Incorporation of a company provides otherwise ... a copy of the instrument appointing a proxy must be delivered to the company, or to any other person on behalf of the company, before the proxy exercises any rights of the shareholder at a shareholders' meeting".

\footnotetext{
Barry v Clearwater Estates supra par 13.

Barry $v$ Clearwater Estates supra par 17.

Barry $v$ Clearwater Estates supra par 20.

Barry $v$ Clearwater Estates supra par 23.

49 Barry $v$ Clearwater Estates supra par 20.
} 
This section manifestly is an alterable provision, as it expressly contemplates that its effect may be altered by a company's MOI. The appellant contended that a distinction should be drawn between the appointment of a proxy in terms of section 58(1) of the Act and the exercise of a proxy in terms of section 58(3)(c). The appellant's argument was that the imposition of the time clause (not less than 48 hours before the appointed time of the meeting) for delivery of a proxy instrument to the company was an alteration in the MOI of Clearwater Estates NPC that related solely to the exercise of the proxy at the meeting and not to the validity of the appointment of the proxy itself, and that it was consequently permitted by section $58(3)(c)$ of the Act. ${ }^{50}$ In other words, the late delivery of an instrument appointing a proxy does not affect the appointment of the proxy itself but means merely that the rights of the proxy cannot be exercised at that particular meeting. ${ }^{51}$ The Supreme of Appeal lucidly rejected as artificial the distinction sought to be drawn by the appellant. ${ }^{52}$ The appointment of a proxy is not made in a vacuum, but has the specific and defined purpose $e^{53}$ of enabling the proxy to participate in, and speak and vote at, a shareholders' meeting on behalf of the shareholder. If this purpose is obstructed by a time bar under section $58(3)(c)$ for the delivery of the proxy instrument, then the very appointment of the proxy itself will be frustrated. ${ }^{54}$ The plain language of sections $58(1)(a)$ and $58(3)(c)$ read together and in their context, with due regard to their apparent purpose, is that a shareholder has the right to appoint any individual as a proxy "at any time", provided that a copy of the instrument appointing the proxy is delivered to the company or to any other person on behalf of the company before the proxy exercises any rights of the shareholder at the meeting. ${ }^{5}$

The court contrasted the provisions on shareholder proxies under the Act with the equivalent provisions in section 189 of the 1973 Act. The 1973 Act (as discussed above) contained no automatic time limit for the appointment of a proxy by shareholders, but had permitted a company in its articles to validly impose a time limit of up to 48 hours before the meeting for the delivery of the proxy instrument. The new Act, in contrast, enables a proxy to be appointed "at any time". ${ }^{56}$ It does away with the minimum period for delivery of the instrument appointing a proxy by providing only that it must be delivered "before" the proxy exercises the rights of the shareholder at the shareholders' meeting. ${ }^{57}$ The Supreme Court of Appeal, with reference to $R v$ Shole, ${ }^{58}$ applied the principle of statutory interpretation that these deliberate changes of expression prima facie indicate a change in the

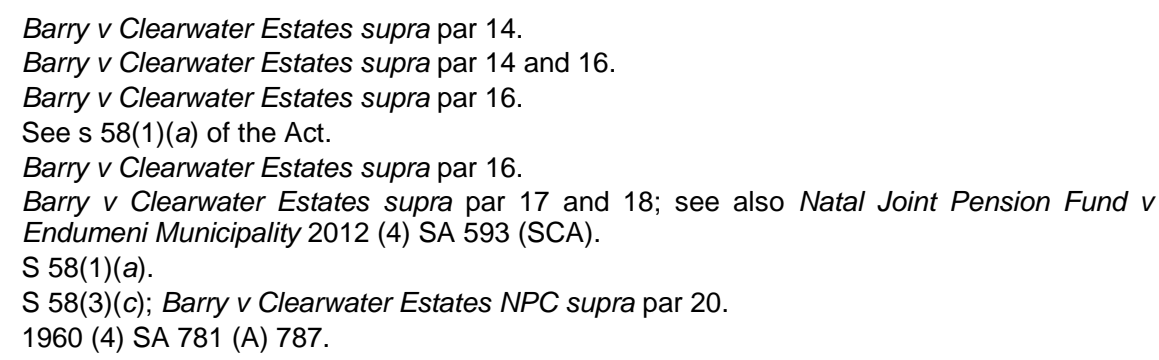


legislative purpose of the provision with regard to the former deadline of 48 hours. ${ }^{59}$

The Clearwater ruling will have a palpable impact on the business practice of South African companies, which customarily requires proxies to be submitted 48 hours in advance of shareholders' meeting. Practical problems could arise in large companies if multitudes of shareholders submit proxy appointments on the day of a shareholders' meeting and shortly before the appointed time of the meeting. The administrative burden involved in validating and verifying proxy appointments could in extreme cases result even in the adjournment of the meeting. While the court acknowledged these practical difficulties, ${ }^{60}$ it declared that, if they are real and not just apparent, they must be resolved by legislative amendment rather than by a strained interpretation of the Act.

\section{ARE PROXIES INVALIDATED BY A CUT-OFF TIME FOR LODGEMENT?}

The decision of the Supreme Court of Appeal was generally cogent and wellreasoned in its interpretation of sections 58(1) and 58(3)(c) of the Act. In an important respect, however, the court seems to have made a fundamental error in its reasoning, creating potential confusion. A pressing practical question arises from the ruling in Clearwater: if the MOI of a company or the proxy forms of a company contain the common condition that the proxy form must be lodged with the company at least 48 hours before the meeting, does this condition render the proxy invalid?

It is erroneously suggested in the judgment of the Supreme Court of Appeal in the Clearwater case that if a company's MOI contains a cut-off time for the lodgement of a proxy instrument, the proxy would not be "effective" at the meeting. ${ }^{61}$ The court, in this regard, states in its analysis of section $189(3)(a)$ of the 1973 Act as follows: ${ }^{62}$

"In terms of the 1973 Act, a provision in a company's articles that the instrument appointing a proxy had to be received by the company more than 48 hours before the meeting, would be void and the proxy would not be 'effective' at the meeting." [emphasis added]

It must be stressed that the court seems to have misconstrued the statutory provision. Section 189(3)(a) (which is set out in paragraph 1 above) makes it clear that what is rendered void is not the proxy itself, but the "provision contained in [the] company's articles" that imposes a time limit longer than 48 hours. It is accordingly submitted that if a company's articles under the 1973 Act provided for a cut-off time of more than 48 hours before the meeting, the practical outcome was that this provision was void, and the company then could not require any deadline at all for the lodgement of shareholder proxies - so that if a proxy showed up at the meeting with his or her proxy form, the proxy would indeed be "effective" at the meeting and the

\footnotetext{
Barry v Clearwater Estates supra par 21.

Barry v Clearwater Estates supra par 22.

Barry v Clearwater Estates supra par 20.

Ibid.
} 
proxy had to be allowed to vote. The flawed analysis of the Supreme Court of Appeal is not merely of historical interest, but seems to have perpetuated a muddle on the validity of proxies under the current company law regime.

To elaborate, assertions have been made by some commentators that the ruling of the Supreme Court of Appeal in Clearwater renders invalid all proxy forms that contain a condition that the proxy must be lodged by a particular deadline before the meeting ${ }^{63}$ (a requirement contained in the proxy forms of most companies, particularly listed companies). It has been further contended that since these proxies are invalid and ineffective, the votes cast by such proxies are also invalidated and that the only persons who are able to vote at the meeting are the handful of shareholders who attend the meeting in person. ${ }^{64}$ It must be emphasised that these assertions stem from a lamentable misinterpretation and misunderstanding of the provisions of the Act.

A proper analysis of the legal position is as follows: section 15(1) of the Act renders void any provision of a company's MOI "to the extent that it contravenes, or is inconsistent with, th[e] Act". Consequently, section 15(1) renders void any provision of a company's MOI that contains a cut-off time for the lodgement of shareholder proxies, on the basis that the cut-off time is inconsistent with the unalterable provision contained in section 58(1) of the Act (that is, that a shareholder may appoint a proxy "at any time"). ${ }^{65}$ Since the cut-off time under the $\mathrm{MOI}$ is void, the result is that the company cannot prescribe any time limit at all for the delivery of proxies - so that proxy forms may be deposited at any time before the proxy exercises the rights of the shareholder at the meeting. If, on the other hand, the deadline for the delivery of proxies is contained in the proxy form itself, section 6(1) of the Act may be relied on. A proxy form would fall within the ambit of an "agreement, transaction [or] arrangement" within the meaning of section 6(1). Section 6(1) of the Act enables the court to declare such a proxy form:

"(a) to be primarily or substantially intended to defeat or reduce the effect of a ... requirement established by ... an unalterable provision of th[e] Act [i.e. section 58(1)]; and

(b) void to the extent that it defeats or reduces the effect of [that] ... requirement." [emphasis added]

Notably, section 6(1) does not invalidate the proxy form in its entirety, but invalidates it only "to the extent that it defeats ... the requirement" that no deadline may be set for the lodgement of proxy appointments. In other words, section 6(1) invalidates only the cut-off condition contained in the proxy form; but it preserves the validity of the proxy form itself and the proxy appointment made thereby - with the result that the vote cast by the proxy remains valid and effective.

In short, it is submitted that the practical impact of the Clearwater ruling is that despite any cut-off condition contained in a company's MOI or in its proxy forms, the proxy forms remain valid and effective. They may validly be

\footnotetext{
Crotty "The Early Proxy Form is Dead" (2017-04-13) Financial Mail.

Ibid.

See also s 15(2)(d), which is discussed under heading 32 above.
} 
lodged with the company at any time before the proxy exercises the rights of the shareholder at the meeting, and may be lodged even at the meeting itself.

\section{CONCLUSION}

In light of the importance of shareholder participation in company affairs, and the impact of shareholder engagement on good corporate governance, the new company law regime has upgraded the rights of shareholder proxies. Of particular practical import is the abolition of the right of a company to impose a cut-off time for the lodgement of shareholder proxies in advance of shareholders' meetings. South African law has in this respect surpassed the comparable legal requirements in English law and Australian law. The English Companies Act of 2006 still permits companies to set a 48-hour limitation, by which time a shareholder must have lodged his proxy form with the company for it to be valid. This is coupled with a mandatory rule in the English statute ${ }^{66}$ that a company's articles cannot require proxy appointments to be delivered any earlier than 48 hours before the meeting. Similar rules apply to the cut-off time for delivery to the company of notice of the termination of a proxy's authority. ${ }^{67}$ The English provision thus is an optin provision that companies may adopt if they so wish. In contrast, the Australian equivalent is an opt-out provision that applies automatically unless a company negates it in its constitution. The Australian statute provides that for the appointment of a proxy to be effective, the appointment (and any relevant power of attorney) must be received by the company at least 48 hours before the meeting, but the 48 -hour period may be reduced by a particular company in its constitution or in the notice of meeting. ${ }^{68}$ Although the liberalised South African provisions on the lodgement of shareholder proxies may cause some practical difficulties for companies, it seems that adaptive measures are already being introduced. Of particular interest is the planned introduction by Strate in mid-2018 of a blockchain system to enable e-proxy voting by shareholders of listed companies. ${ }^{69}$ This system will facilitate online voting by shareholders, who will submit votes by the use of an authorised login. The advantage is that votes will be automatically processed, thus giving the listed company voting results in real time and, furthermore, eliminating the risk of errors or manipulation in the counting of shareholder proxies. ${ }^{70}$

S 327 of the English Companies Act, 2006.

S 330(6) of the English Companies Act, 2006.

S 250B and 250B(5) of the Australian Corporations Act, 2001.

69 Ziady "Strate e-voting Plan for Proxies" (2017-07-25) Business Day Companies and Markets 9 .

70 Ibid. 